\title{
ON THE SYSTEMATIC RELATIONS OF THE AMMODYTOID FISHES.
}

\author{
By Theodore Gill,
}

Honorary Associate in Zoology.

There are few fishes respecting whose affinities there has been so much diversity of opinion, especially in later years, as the Sand Launces or Ammodytids. By Artedi, the genus embracing them (Ammodytes) was referred next to Coryphæna, and by Linnæus it was naturally placed in the unnatural order of Apodes, no ventral fins being developed. For the same reason it was referred by later ichthyologists who adopted families to the same family as other apodal fishes with long dorsal and anal fins. By all except Bonaparte, during the first half of the nineteenth century, it was associated with Ophidium in the same family.

In 1846 Bonaparte first separated the genus from the family of Ophidiids, but retained it near that group.

In 1861 Gill adopted the family under the name Ammodytoidx, modifying the name in accordance with the principle promulgated by Agassiz, who insisted that all family names derived from the Greek should have the termination "-oidæ." The family was removed from association with the "Ophidioidx" and placed next after Atherinoidx, which succeeded Mugiloidx and Polynematoidx. Subsequently (1872) he reverted to the current views, approximating it to the Ophidiids, but isolating it as the representative of a distinct superfamily-Ammodytoidea.

In 1896 Jordan and Evermann (p. 832) isolated the Ammodytidæe as a "group Ammodytoidei" after the Sphyrænidæ and Polynemidx and before the Berycoidei, adding that the group "is of unknown relations." "In the character of the mouth and gill structures it resembles 
the Atherinidix rather than the Ophidioidei." "The family is placed by Jordan and Gilbert between the Percesoces and the Scombroidei. Knowing no better place for it we leave it next to the Percesoces."

In $1901 \mathrm{~A}$. Smith Woodward, acting under the advice of A. Boulenger, ${ }^{a}$ referred the family to the Percesoces, next before the Scombresocidæ and after the extinct Crossognathidæ, in the first section of the suborder, the second embracing those having "pelvic fins with anterior" spine."

In 1903 David Starr Jordan isolated in a distinet genus (Embolichthys) a fish previously described by Jordan and Evermann (1902) as Bleekeria mitsikurii. So similar is it to Bleekeria, and therefore to Ammodytes, that the existence of jugular ventral fins was at first overlooked. Later they were discovered and the bearing of their existence on the question of relationship of the family considered. Their presence, Jordan declared, "shows that the Ammodytidx have no affinity with the Percesoces, nor with the extinct family of Cobitopsidx. Their

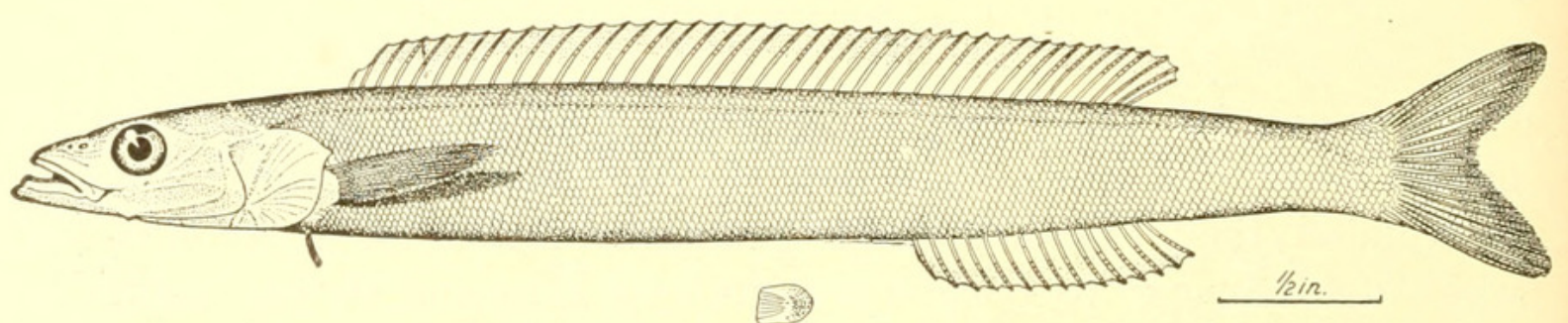

Fig. 1.-EMbolichthys MitsikuriI.

place must be near the Ophidiidæ, as supposed by earlier and some recent writers."

In 1904 Boulenger reiterated the views published by Woodward, combining Scombresocidæ and Ammodytidæ alone in a first section of the suborder Percesoces.

The discovery of jugular ventrals in Embolichthys is extremely important and conclusively demonstrates (that genus being undoubtedly related to Ammodytes) that the family is not at all related to the Percesoces and that the affiliation, with the family, of the extinct Cobitopsis was misjudged. The question then recurs, What is the relationship of the family? An examination of various species of Ammodytids reminded the writer of the genus Hemerocœtes, of New Zealand. That remarkable genus has a form considerably like an Ammodytid's; all the dorsal rays are simple but articulated, and curiously the supramaxillaries are produced into anterior spiniform tips. The condition of the scapular arch, however, appears to be different; nevertheless the resemblance in many respects is so great as to demand a comparative anatomical investigation.

$a$ "For the determination of the systematic position of this genus, the writer is indebted to Mr. G. A. Boulenger." (A. Smith Woodward, IV, p. 354.) 
The genera Hemerocktes and Trichonotus have been associated by all authors except the writer in the same family - Trichonotidæ-but their relationship, if such it be, requires verification.
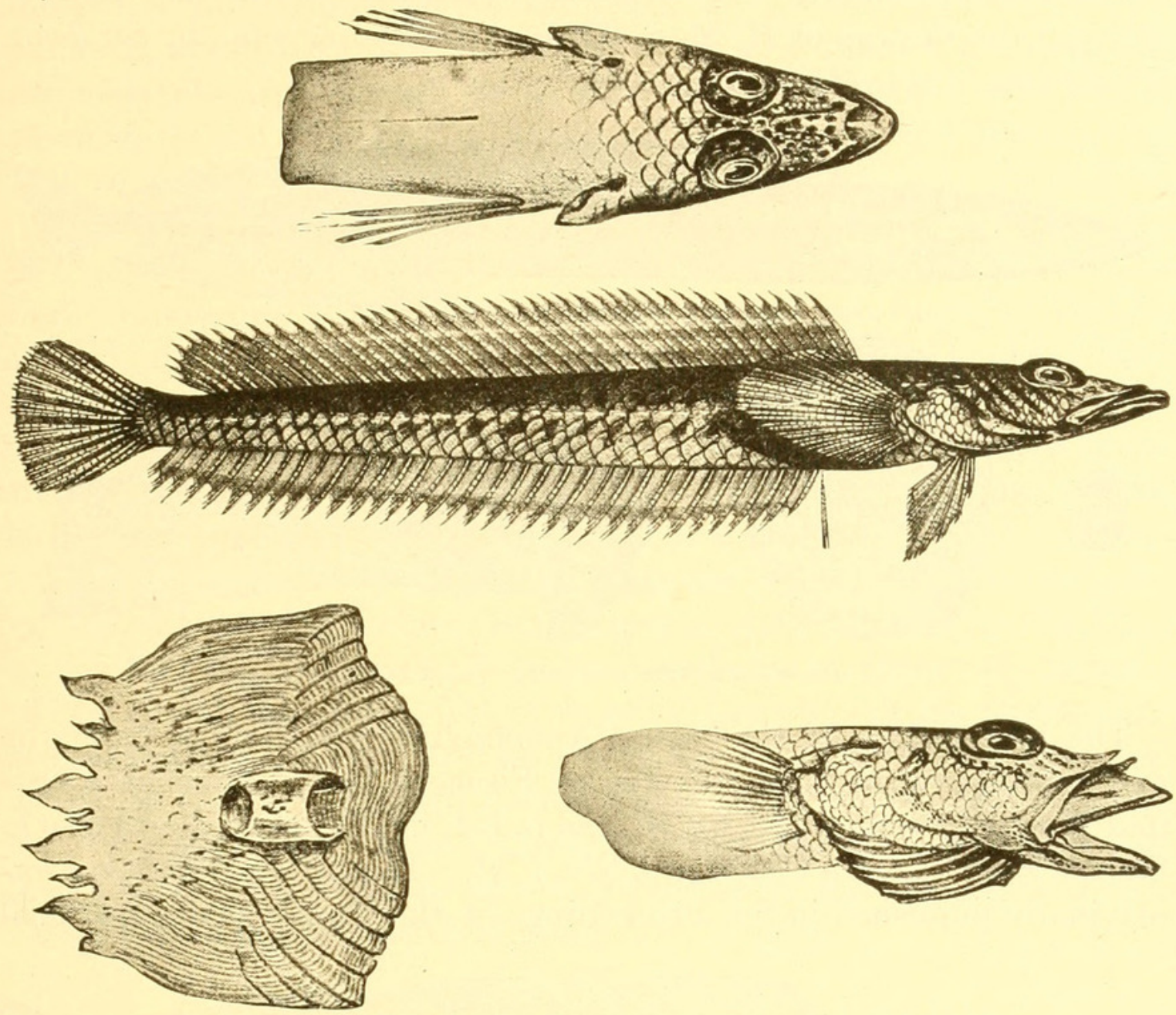

Fig. 2.-Hemerocates ACANTHORHYNCHus. (After Richardson.)

A partial synonymy of the family Ammodytidæ follows:

\section{AMMODYTID E.}

Family names.

Ammodytidx Bonaparte, Cat. Metod Pesci Europei, 1846, pp. 7, 40.

Pantopteres (idiapodes) Dumérit, Ichthyologie Anal., 1856, p. 213.

Ammodytoidx Gill, Cat. Fishes E. Coast N. Am., 1861, p. 40.

Ammodytids Richardson, Museum Nat. Hist., Zool., 1865, p. 112.

Ammodytx Fitzinger, Sitzungsber. k. Akad. Wissensch. (Wien), LXVII, 1. Abth.,

1873 , p. 43.

Ammodytidx Moreau, Hist. Nat. Poissons France, III, 1881, p. 215.

Ammodytidx Sмitт, Hist. Scand. Fishes, 1895, pp. 462, 557, 567.

Ammodytidx Woodward, Cat. Fossil Fish B. M., IV, 1901, p. 354.

Ammodytidx Jordan, Proc. U. S. Nat. Mus., XXVI, 1903, p. 693.

Ammodytidæ Boulenger, Ann. Mag. Nat. Hist. (7), XIII, 1904, p. 175.

Subfamily names.

Ammodytinæ Bonaparte, Nuovi Annali delle Se. Nat., II, 1838, p. 133; IV, 1840 p. 276 .

Ammodytiformes Bleeker, Enum. Sp. Piscium Archipel. Indico, 1859, p. xxv.

Ammodytina Günther, Cat. Fishes B. M., IV, 1862, p. 384. 
As the illustrations of Hemerocates are published in a work to be found in very few libraries, figures representing the entire fish, the head from above and laterally (with mouth opened to show jaws), and a scale are reproduced. The originals were published in the "Ichthyology of the Voyage of H. M. S. Erebus and Terror," etc., by Sir John Richardson, $1844-1848$, on plate 54 .
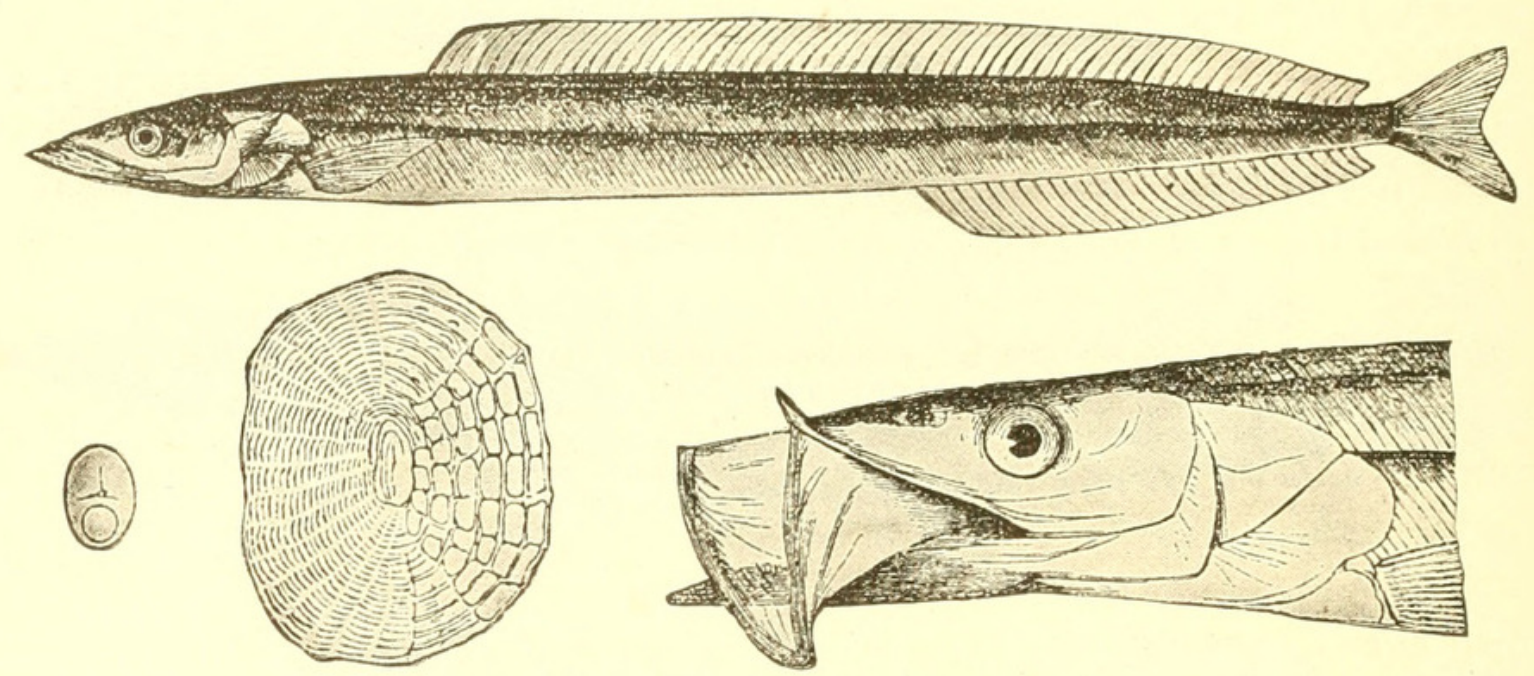

Fig. 3.-Ammodyes tobianus. (After Benecke.)

The illustrations of the typical Ammodytids are derived from the excellent figures in Benecke's Fische, Fischerie und Fischzucht in Ostund Westpreussen (p. 100, fig. 80, and p. 101, fig. 81), reproduced also in Smitt's Scandinavian Fishes (pp. 570, 574). That of Embolichthys was originally published in the Proceedings of the United States National
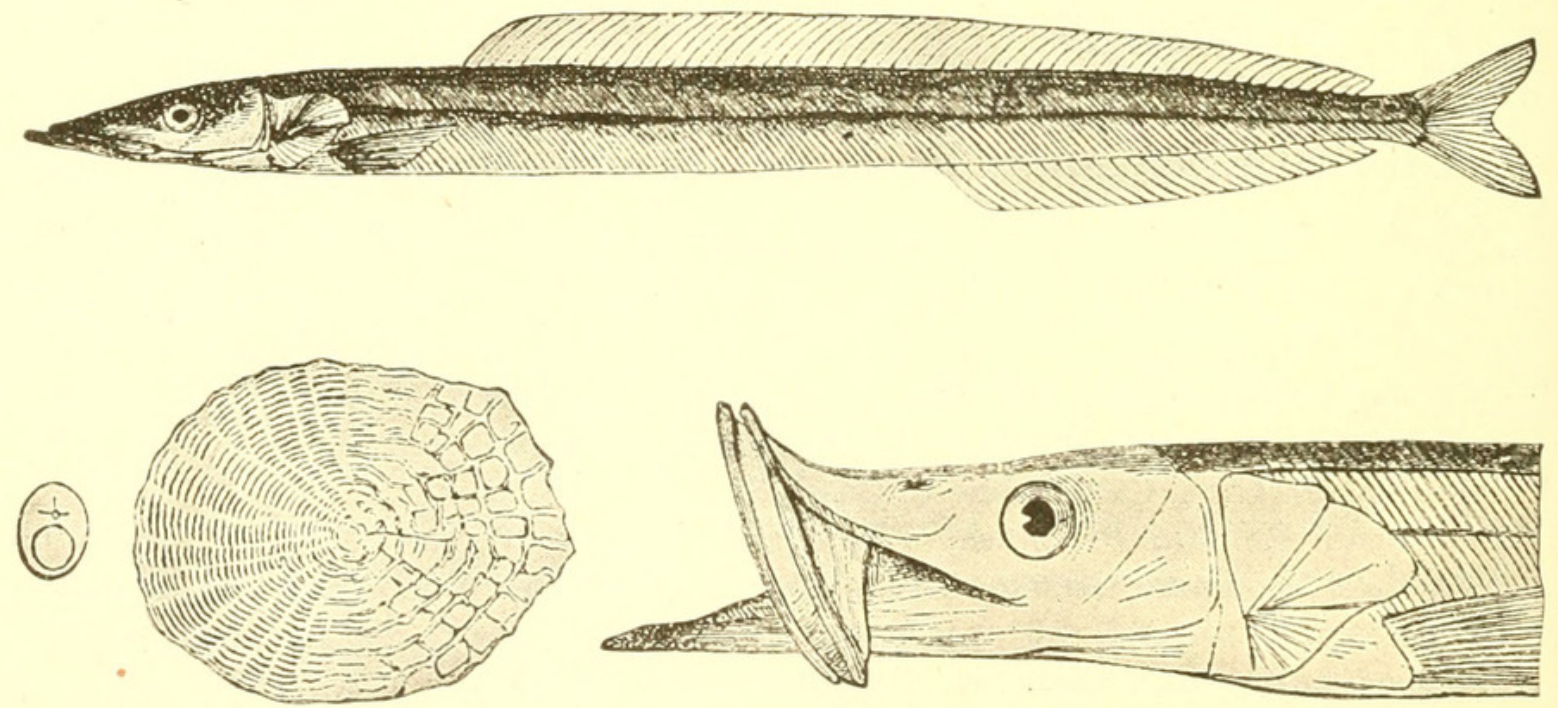

FiG. 4.-Hyperoplus lanceolatus. (After Benecke.)

Museum for 1902 (XXV, p. 334), and reproduced in the Proceedings for 1903 (XXVI, p. 693).

The figures of the typical Ammodytids are added to show how similar they are to Embolichthys in form, the development of the jaws, characteristic opercular apparatus, and form and proportions of the fins. In all these respects they appear to contrast with the Cobitop- 
sids. A reexamination of the questions involved and especially comparison of the anatomical peculiarities of the Ammodytids and the Hemerocœetids are greatly to be desired. Lack of material prevents the writer from entering upon the task.

The figures of the opened mouth show how distinct the northern Ammodytids are-enough so to warrant recognition of the genera Ammodytes and Hyperoplus, suggested by Günther and admitted by Gill, as well as by Jordan and Evermann. In the typical Ammodytes (tobianus) the intermaxillaries are protrusile and the supramaxillaries have peculiar dentiform tubercles connected with the vomer; in Hyperoplus (lanceolatus) the intermaxillaries are not protrusile, at least in the old, and the vomer is armed with a pair of teeth which have been confounded with the supramaxillary tubercles of Ammodytes.

As to Cobitopsis, I am unable to appreciate the reasons for the reference of the genus to the "Percesoces." The ventral fins are said to have "only about 6 divided rays," and it has short "dorsal and anal fins similar and directly opposed, close to the caudal." On the evidence presented I should have referred the genus to the neighborhood at least of the Esocida and Poeciliidæ, if not with one of them-the latter if the jaws really do agree. The distinctive characters of the Cobitopsidx are not evident. There may have been unpresented reasons, however, which led the very distinguished and able ichthyologists of London to the conceptions they have published. The jaws are not represented in the figure of Cobitopsis acutus published in the Catalogue of the Fossil Fishes in the British Museum (IV, p. 355). 


\section{$2 \mathrm{BHL}$ Biodiversity Heritage Library}

Gill, Theodore. 1904. "On the systematic relations of the ammodytoid fishes." Proceedings of the United States National Museum 28(1388), 159-163. https://doi.org/10.5479/si.00963801.28-1388.159.

View This Item Online: $\underline{\text { https://www.biodiversitylibrary.org/item/52788 }}$

DOI: https://doi.org/10.5479/si.00963801.28-1388.159

Permalink: https://www.biodiversitylibrary.org/partpdf/51060

\section{Holding Institution}

Smithsonian Libraries

\section{Sponsored by}

Smithsonian

\section{Copyright \& Reuse}

Copyright Status: Public domain. The BHL considers that this work is no longer under copyright protection.

This document was created from content at the Biodiversity Heritage Library, the world's largest open access digital library for biodiversity literature and archives. Visit BHL at https://www.biodiversitylibrary.org. 